\title{
Influence of Apion sp. (Brentidae, Apioninae) stem-galls on induced resistance and leaf area of Diospyros hispida (Ebenaceae)
}

\author{
Rodrigo A. de Souza ${ }^{1}$, Rafael Nessim² ${ }^{2}$ Jean C. Santos ${ }^{3}$ \& Geraldo Wilson Fernandes ${ }^{3,4}$
}

${ }^{1}$ Laboratório de Ecologia de Processos e Qualidade de Água, Departamento de Biologia Geral, Caixa Postal 486, ICB/Universidade Federal de Minas Gerais, 30161-970 Belo Horizonte-MG, Brasil.

${ }^{2}$ Ecologia de Populações, Departamento de Biologia Geral, Caixa Postal 486, ICB/Universidade Federal de Minas Gerais, $30161-970$

Belo Horizonte-MG, Brasil.

${ }^{3}$ Ecologia Evolutiva \& Biodiversidade/DBG, Caixa Postal 486, ICB/Universidade Federal de Minas Gerais, 30161-970 Belo Horizonte-MG, Brasil. ${ }^{4}$ Corresponding author

\begin{abstract}
Influence of Apion sp. (Brentidae, Apioninae) stem-galls on induced resistance and leaf area of Diospyros hispida (Ebenaceae). We addressed the influence of the stem galls induced by an unidentified species of Apion - sensu lato (Brentidae, Apioninae) on the host plant, Diospyros hispida (Ebenaceae) leaf area and induced resistance against a Cecidomyiidae (Diptera) leaf galls. The study was performed in a cerrado vegetation in Serra do Cipó, southeastern Brazil. Although the number of leaves produced on galled and ungalled shoots did not differ statically $(p>0.05)$, the presence of the apionid galls influenced the area of the leaves on the attacked shoots of $D$. hispida. Leaves on galled stems were approximately $50 \%$ smaller compared to leaves in healthy stems. The average of the cecidomyiid leaf galls successfully induced on healthy shoots was higher compared to galls successfully induced on shoots galled by the apionid. The same pattern was found for the abundance of hypersensitive reactions against the cedidomyiid gall induction. Therefore, the ability of the cecidomyiid to successfully induce galls was not influenced by the apionid galler.
\end{abstract}

KEYWORDS. Cecidomyiidae; Cerrado; hypersensitive reaction; insect galls; insect herbivory; Serra do Cipó.

RESUMO. Influencia das galhas caulinares de Apion sp. (Brentidae, Apioninae) sobre a resistencia induzida e área foliar de Diospyros hispida (Ebenaceae). Neste estudo verificamos a influência de galhas de ramos induzida por uma espécie não identificada de Apion sp. (Brentidae, Apioninae) sobre a área foliar da planta hospedeira Diospyros hispida (Ebenaceae) e na resistência induzida contra galhas de folhas de um Cecidomyiidae (Diptera). Este estudo foi conduzido em uma vegetação de cerrado na Serra do Cipó, sudeste do Brasil. Embora o número de folhas produzidas nos ramos galhados e não galhados não tenha diferido estaticamente $(p>0,05)$, a presença das galhas de Apion sp. influenciou a área foliar nos ramos atacados de $D$. hispida. Folhas de ramos com galhas foram aproximadamente $50 \%$ menores quando comparadas a folhas em ramos saudáveis. A média de galhas foliares do Cecidomyiideae que se formaram com sucesso em folhas de ramos saudáveis foi maior quando comparado à média de galhas bem sucedidas em folhas de ramos galhados pelo Apion sp.. O mesmo padrão foi encontrado para a abundância de reações hipersensibilidade contra a formação de galhas do cecidomyí́deo. Portanto, a habilidade do cecidomyiídeo de induzir galhas não foi influenciada pelas galhas de Apion sp..

PALAVRAS-CHAVE. Cecidomyiidae; Cerrado; galhas de insetos; herbivoria por insetos; reação de hipersensibilidade; Serra do Cipó.

Gall induction by insects often act as physiological nutrient sinks on their host plants, because nutrients move from ungalled tissues and neighboring plant parts to the gall itself (Kirst 1974, Larson \& Whitham 1991). In addition to modify the architecture of the attacked and neighboring host organs, galls may also affect the entire host plant (e.g. Mani 1964, Hartnett \& Abrahamson 1979, Fernandes 1987, Fernandes et al. 1999), thereby diminishing the performance of the host. Gall formation reduces flower, fruit, seed, and biomass production of several host plants (McCrea et al. 1985, Sacchi et al. 1988, Fernandes et al. 1993, Fernandes \& Ribeiro 1990, Souza et al. 1998).

In response to the feeding mode of galling insects, many plant species evolved an elaborated defense mechanism by which the induced cells are readily found and killed. This mechanism has argued to be a hypersensitive response (Fernandes 1990, Fernandes et al. 2000). Through a series of cascade morphological, biochemical and physiological events, the host plants elicit this induced-type of resistance, which terminates with the localization, confinement and death of the attacked tissue (Fernandes et al. 2000, Fernandes \& Negreiros 2001).

Diospyros hispida DC. (Ebenaceae) is a woody shrub that reaches two meters high and is found in the Cerrado (savanna) and rupestrian fields of Brazil (Sano \& Almeida 1998). In the cerrado of Serra do Cipó, in southeastern Brazil, this host species is attacked by two different species of galling insects. One of these galls is induced by an unidentified species of 
Apion sp. (Araújo et al., 1995). Because some authorities have recently split the genus up (veja Alonzo-Zarazaga \& Lyal 1999), we are uncertain which of the new genera our species belongs to. Hence, heretofore we refer to this species as Apion sp. "sensu latu" (Brentidae: Apioninae) (see Kissinger 1968, see also Wibmer \& O'brien (1986). The apionid attack new shoots inducing the growth of large galls which are globular, green and covered by a dense mat of short trichomes. Many galling larvae are found inside the galls that become brown and hard as they age. The second gall is induced by a still unidentified species of Cecidomyiidae (Diptera) (VC Maia, pess.com.) on the leaves of $D$. hispida. These galls are simple swellings on the leaf surface that have a discoid shape, are bright green, glabrous, and possess one chamber where only one larva is found.

Casual observations indicated that D. hispida elicits a hypersensitive reaction against the leaf galls induced by the cecidomyiid but not against the shoot galls. The reactions are observed as necrotic spots of rounded shape of reddish coloration on the leaf lamina on shoots with and without the apionid galls. The co-occurrence of apionid and cecidomyiid galls offers a scenario where we can observe whether the shoot galls influence the performance of the leaf galling cecidomyiid by evaluating Diospyros hispida's ability to elicit the hypersensitive reaction to the leaf gall. Two questions were addressed in this study: Does the gall induced by the apionid beetle affect the leaf area of attacked shoots? We postulated that as stem galls often deprives the terminal portion of attacked stems of nutrients and photosynthates (see Mani 1964, Souza et al. 1998), leaves would be smaller. How does the host plant ability to elicit a hypersensitive response is influenced by the presence of shoot galls? We postulated that the abundance of cecidomyiid leaf galls would be higher on leaves on stems attacked by the apionid species, because these leaves would not be able to elicit the hypersensitive response fast enough in comparison to leaves on healthy stems (see Fernandes et al. 2000).

The study was done in the Parque Nacional da Serra do

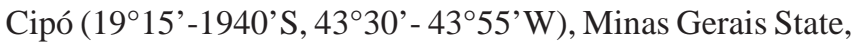
Brazil, at 850 meters a.s.l. Diospyros hispida was found only in a small area of disturbed cerrado vegetation (see Fernandes 1994) of approximately $10,000 \mathrm{~m}^{2}$. In November of 2002 we randomly selected 15 individuals of Diospyros hispida to answer the questions raised. From each individual plant we randomly selected three pairs of galled shoots and their nearest neighbor healthy shoots (without Apion sp. galls) to compare both the impact of the stem gall on leaf area, and stem gall effect on the leaf gall success. We counted all leaves present on each shoot and then randomly collected three from each shoot ( $\mathrm{n}=18$ leaves per plant), numbered them according to the plant individual and presence of stem gall, placed in plastic bags and took them to the laboratory for further study.

To answer the question on the impact of the stem gall on the leaf area of $D$. hispida, leaves of galled stems and healthy stems were scanned on a digital scanner and the images analyzed with the aid of the CIAS 2.0 program. To answer
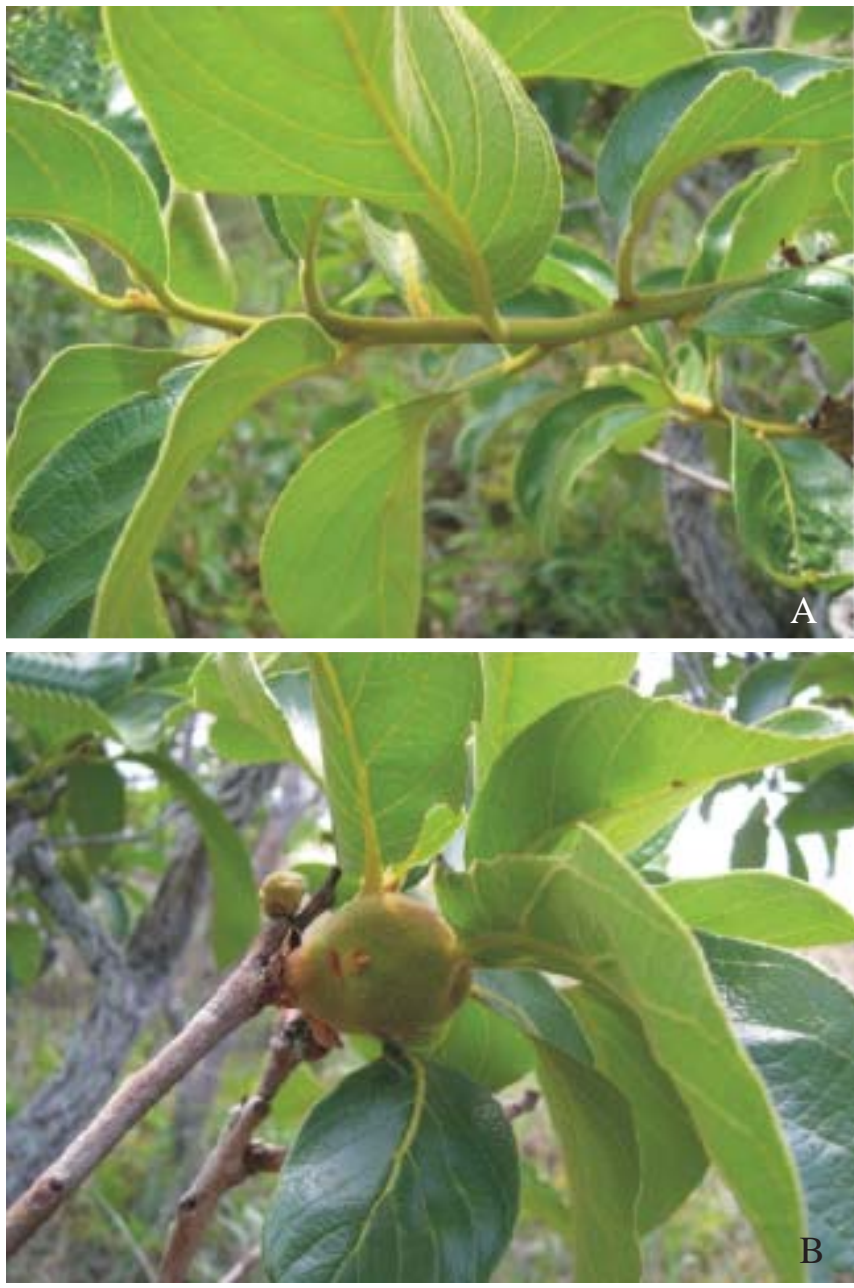

Fig. 1. (A) Healthy shoot; (B) apionid galls on shoot of Diospyros hispida (Ebenaceae).

whether the stem galls influenced the ability of the host plant in eliciting a hypersensitive response to the leaf galling cecidomyiid, we counted all gall successfully formed and all hypersensitive reactions (galls found and killed by the plant) on leaves from both stem-galled and healthy shoots of $D$. hispida (see Fernandes \& Negreiros 2001 for details). We then used the t-test for dependent samples to compare the effect of the shoot galls on leaf area and plants ability to elicit the hypersensitive reaction against the cecidomyiid galler.

The number of leaves produced on shoots galled by the apionid $(5.7 \pm 0.7, \bar{x} \pm \mathrm{SE})$ did not differ statistically from those produced on ungalled shoots $(6.4 \pm 1.1, \bar{x} \pm \mathrm{SE}, p=0.39, \mathrm{n}=$ 30). On the other hand, shoots attacked by the apionid were clearly shorter than ungalled shoots. The presence of the apionid galls influenced the area of leaves on attacked stems of $D$. hispida. Leaves on galled stems were approximately $50 \%$ smaller compared to leaves on healthy shoots. These results were expected as the apionid shoot galls are large and may induce a strong sink for plant photosynthates. Shoot galls are known to strongly influence the vascular bundles of the 
attacked organ (Mani 1964). In many cases, they induce drastic changes in the architecture and performance of the attacked shoot, often causing their death (e.g. Silva et al. 1996, Souza et al. 2001).

The number of cecidomyiid leaf galls successfully induced on healthy shoots $(29.3 \pm 4.8, \bar{x} \pm \mathrm{SE}, \mathrm{n}=15)$ was higher compared to galls successfully induced on shoots galled by the apionid $(22.0 \pm 3.0, \bar{x} \pm \mathrm{SE}, \mathrm{n}=15)$ (dependent $\mathrm{t}$-test $=$ 28.2 , df $=29, p<0.0001, \mathrm{n}=30$ ). The same pattern was found for the abundance of hypersensitive reactions. Leaves on healthy stems showed a higher number of hypersensitive reactions $(27.7 \pm 9.8, \bar{x} \pm \mathrm{SE}, \mathrm{n}=15)$ compared to leaves on shoots attacked by the apionid $(17.0 \pm 5.8, \bar{x} \pm \mathrm{SE}, \mathrm{n}=15)$ (dependent t-test $=15.37, \mathrm{df}=29, p<0.0001, \mathrm{n}=30$ ).

These data showed that approximately $60 \%$ of the attack [galls successfully formed plus plant hypersensitive reactions (each reaction is equivalent to a dead larva = gall failure, see Fernandes et al. 2000)] by the leaf galling species was centered on healthy shoots (shoots free of galls induced by the apionid). In addition, approximately $50 \%$ the attempts of the leaf galling species to induce galls on healthy stems resulted on failure due to plant hypersensitive responses. Otherwise, on shoots attacked by the apionid, the failure to induce galls by the leaf galling species was reduced to approximately $42 \%$. Altogether, there appears to exist a trend for a balance on the percentage of attack and induced resistance; i.e., more attempts to induce galls on healthy stems resulted on more galls being killed. The reasons for that trend are unknown at present and hence deserve detailed studies. Fewer attempts to induce galls were recorded on leaves on shoots galled by the apionid but on these approximately the same percentage (42.5\%) were found and killed by the plant when compared to healthy stems. Therefore, one might suspect that resistance to gall induction or impact of the shoot galling species are phenomena that can reflect on the entire plant. Furthermore, these data do not corroborate our hypothesis that predicted higher success of the leaf galler on stems already stressed by the stem galler. On the other hand more detailed studies are needed to further test such hypothesis.

Acknowledgements. We thank an anonymous reviewer for his contribution to an early version of the ms, B. D. Raniere, D. Negreiros, R. De Luca, M. C. G. Lisboa, and D. R. S. Alonso for field help, J. Lombardi for the identification of the plant, D. Yanega for the identification of the galling weevil and the Parque Nacional do Serra do Cipó for allowing the study in the park. This study was supported by CNPq (304851/2004-3, 472491/2003-2, 140071/2003-2) and Fapemig (CRA 583/03).

\section{REFERENCES}

Alonso-Zarazaga, M. A. \& C. H. C. Lyal. 1999. A world catalogue of families and genera of Curculionoidea (Insecta: Coleoptera) (excepting Scolytidae and Platypodidae). Barcelona, Entomopraxis, $315 \mathrm{p}$.

Araújo, L. M.; A. C. F. Lara \& G. W. Fernandes. 1995. Utilization of Apion sp. (Coleoptera: Curculionidae) galls by an ant community in southeastern Brazil. Tropical Zoology 8: 319-324.

Fernandes, G. W. 1987. Gall forming insects: their economic importance and control. Revista Brasileira de Entomologia 31: 379-398.

Fernandes, G. W. 1990. Hypersensitivity: a neglected plant resistance mechanism against insect herbivores. Environmental Entomology 19: 1173-1182.

Fernandes, G. W. \& S. P. Ribeiro. 1990. Plant response to herbivory: two examples from the neotropics. Ecotropicos 3: 77-86.

Fernandes, G. W.; A. F. L. Souza \& C. F. Sacchi. 1993. Impact of Neolasioptera (Diptera: Cecidomyiidae) stem galler on its host plant, Mirabilis linearis (Nyctaginaceae). Phytophaga 5: 1-6.

Fernandes, G. W. 1994. Plano de ação emergencial do Parque Nacional da Serra do Cipó. IBAMA Brasília. 179p.

Fernandes, G. W.; F. M. C. Castro \& E. S. A. Marques. 1999. Leaflet abscission caused by a gall induced by Melaphis rhois (Aphididae) on Rhus glabra (Anarcadiaceae). International Journal of Ecology and Environmental Sciences 25: 63-69.

Fernandes, G. W.; T. G. Cornelissen; R. M. S. Isaias \& T. A. F. Lara. 2000. Plants fight gall formation: hypersensitivity. Ciência \& Cultura 52: 49-54.

Fernandes, G. W. \& D. Negreiros. 2001. The occurrence and effectiveness of hipersensitive reaction against galling herbivores across host taxa. Ecological Entomology 26: 46-55.

Hartnett, D. C. \& W. G. Abrahamson. 1979. The effects of stem gall insects on life history in Solidago canadensis. Ecology 60: 910917.

Kissinger, D. G. 1968. Curculionidae subfamily Apioninae of North and Central America with reviews of the world genera of Apioninae and world subgenera of Apion Herbst (Coleoptera). Taxonomic Publications. Suth Lancaster, Massachusetts.

Kirst, G. O. 1974. Zur Physiologie der Galle von Mikiola fagi Htg. auf Blättern von Fagus sylvatica L. 3. ${ }^{14} \mathrm{CO}_{2}$-Licht- und Dunkelfixierung der Galle. Biochem Physiol Pflanzen 165: 457-466.

Larson, K. C. \& T. G. Whitham. 1991. Manipulation of food resources by a gall-forming aphid: the physiology of sink-source interactions. Oecologia 88: $15-21$.

Mani, M. S. 1964. The ecology of plant galls. The Hague, Netherlands.

McCrea, K. D.; W. G. Abrahamson \& A. E. Weis. 1985. Goldenrod ball gall effects on Solidago altissima: ${ }^{14} \mathrm{C}$ translocation and growth. Ecology 66: 1902-1907.

Sacchi, C. F.; P. W. Price; T. P. Craig \& J. K. Itami. 1988. Impact of the shoot galler attack on sexual reproduction in the arroyo willow. Ecology 69: 2021-2030.

Sano, S. M. \& S. P. Almeida. 1998. (Eds.) Cerrado: ambiente e flora. EMBRAPA-CPAC. Planaltina. 556p.

Silva, I. M.; G. I. Andrade; G. W. Fernandes \& J. P. F. Lemos. 1996. Parasitic relationship between a gall-forming insect Tomoplagia rudolphi (Diptera: Tephritidae) and its host plant (Vernonia polyanthes, Asteraceae). Annals of Botany 78: 45-46.

Souza, A. L. T.; G. W. Fernandes; J. E. C. Figueira \& M. O. Tanaka. 1998. Natural history of a gall-inducing weevil Collabismus clitellae (Coleoptera: Curculionidae) and some effects on its host plant Solanum lycocarpum (Solanaceae) in southeastern Brazil. Annals of the Entomological Society of America 91: 404-409.

Souza, A. L. T.; M. O. Tanaka; G. W. Fernandes \& J. E. C. Figueira. 2001. Host plant response and phenotipic plasticity of a galling weevil (Collabismus clitellae: Curculionidae). Austral Ecology 26: $173-178$. 